\title{
Differential aerobic decomposition between a native and exotic macrophytes of tropical reservoirs
}

\author{
Chiba, WAC. ${ }^{a *}$, Cunha-Santino, MB. ${ }^{b}$ and Bianchini Junior, $I .^{b}$ \\ ${ }^{a}$ Instituto Latino-Americano de Ciências da Vida e da Natureza, Universidade Federal da Integração Latino-Americana - \\ UNILA, Av. Tancredo Neves, 6731, CP 2044, CEP 85867-970, Foz do Iguaçu, PR, Brazil

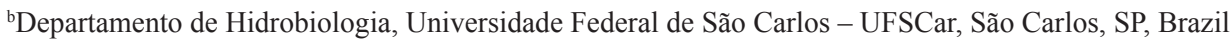 \\ *e-mail: wagner.castro@unila.edu.br
}

Recieved: August 8, 2014 - Accepted: October 14, 2014 - Distributed: May 31, 2015

(With 1 figure)

Decomposition is essential for carbon and nutrients cycling for all ecosystems (Hoorens et al., 2003). In lentic aquatic environments (e.g., lakes and reservoirs), aquatic macrophytes are the main autochthonous detritus source, and their mineralization is fundamental for maintaining biogeochemical cycles, associated with energy flux and detritus food-webs. (Bianchini Junior et al., 2014). In disturbed systems, some of these aquatic plants are potentially invasive due its high growth rates and elevated productivity (Pieterse and Murphy, 1990). The excessive growth of invasive submerged macrophytes, and consequently accumulation of biomass, provides increased rates of decomposition, leading to reductions in dissolved oxygen concentrations, changes of redox potential, increases of detritus accumulation rates and consequential changes in biogeochemical cycles (Reddy and Delaune, 2008). Considering the need for understand nutrient and carbon cycling processes involving invasive macrophytes, we compared the aerobic decomposition of two important same niche submerged macrophytes, the Brazilian native Egeria densa Planch. and the exotic Hydrilla verticillata (L.f.) Royle.

We collected and processed samples of $H$. verticillata, E. densa and water in the Jupiá and Porto Primavera reservoirs, both located in Paraná River Basin, Brazil (Chiba de Castro et al., 2013) and aerobic incubations and carbon fraction estimations were carried out in the laboratory (Cunha-Santino and Bianchini Junior, 2002) during 80 days. The oxygen consumption (OC) kinetics from mineralization of aquatic plant detritus was fitted using a non-linear method (Levenberg-Marquardt iterative algorithm; Bianchini Junior et al., 2014). To verify differences among aerobic decomposition, a co-variance analysis test (ANCOVA) was applied (PAST, v.2.01).

The kinetics parameterization obtained from the fitting of experimental data presented high determination coefficients; $H$. verticillata presented significant (ANCOVA; $\mathrm{F}=36.42, \mathrm{p}<0.001$ ) higher oxygen consumption than $E$. densa (Figure 1). The significant differences between the OC from $H$. verticillata and $E$. densa mineralization can be explained by the lignin content. $H$. verticillata presents $50 \%$ higher refractory fraction content than $E$. densa due to lignin content (Chiba de Castro et al., 2013). The most recalcitrant quality of lignin, when compared with the other fibers (i.e. cellulose and hemicellulose), requires a great proportion of energy allocated to mineralization (Kourtev et al., 2002) and consequently high OC. The accentuated $\mathrm{OC}$ in the first days occurred due mineralization of labile compounds, displaying a high velocity and high oxygen demand. The subsequent decrease in OC is related with predominance of refractory compounds, with lower mineralization rates. Refractory fraction can be

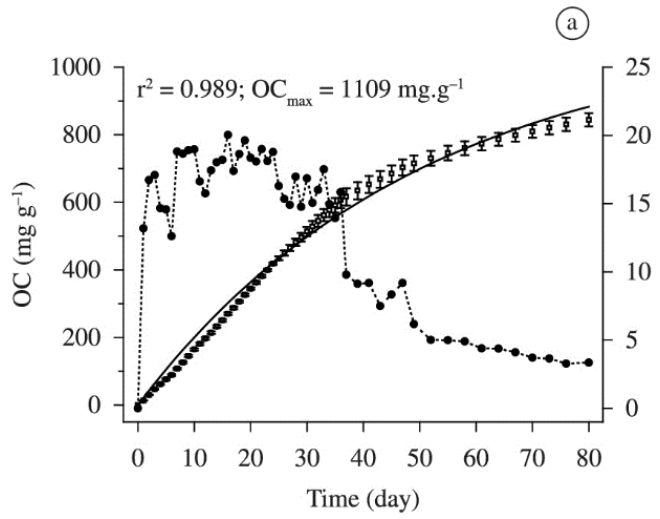

(b)

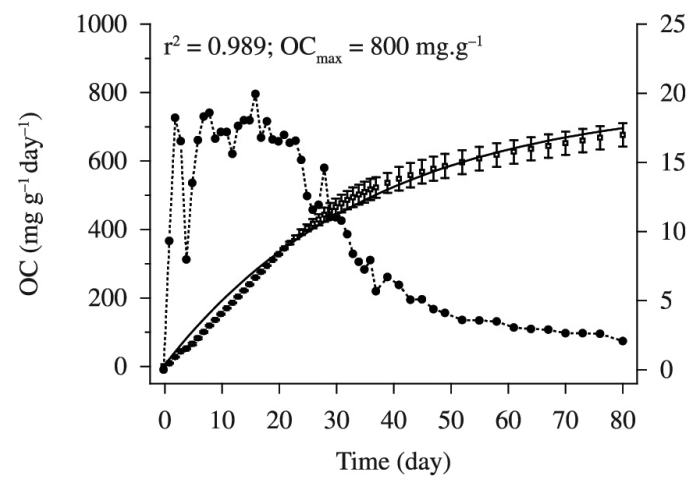

Figure 1. Temporal changes of oxygen consumption (OC) of (a) Hydrilla verticillata and (b) Egeria densa detritus in aerobic incubations. 
metabolized 10 to 20 times slower than the labile fraction (Gillon et al., 1994). Changes in the species composition of plant communities could be result in changes in the enzymatic activities of the microbiota, mainly in heavily invaded communities by exotic species and could also explain these differences found (Kourtev et al., 2002). In addition, the temporal evaluation of $\mathrm{OC}$ allows the indirect description of microorganism metabolism as result of decay processes in aquatic ecosystems, once the recognition the proportionality among the substrate disappearance and the formation of microbial biomass products (Bianchini Junior et al., 2006).

$H$. verticillata and Egeria native species have so many ecological and morphological similarities that they probably compete in the Paraná basin (Sousa et al., 2009). However, due to faster growth, $H$. verticillata would present the highest competitive potential (Bianchini Junior et al., 2010). The higher oxygen demand of detritus and the potential dominance upon other submerged native macrophytes, provides changes in the ecosystem in medium and long term as accumulation of particulate refractory material in the sediments and the increased of anaerobic heterotrophy.

\section{Acknowledgements}

This study was supported by CESP (P\&D ANEEL, proc. $n^{\circ} 0061-011 / 2006$ ), $\mathrm{CNPq}$ (proc. $\mathrm{n}^{\circ} 302935 / 2007-0$ and 131406/2010-8) and FAPESP (proc. $n^{\circ}$ 2007/002683-7).

\section{References}

BIANCHINI JUNIOR, I., CUNHA-SANTINO, MB. and PERET, AM., 2006. A mesocosm study of aerobic mineralization of seven aquatic macrophytes. Aquatic Botany, vol. 85, no. 2, p. 163-167. http://dx.doi.org/10.1016/j.aquabot.2006.03.001.

BIANCHINI JUNIOR, I., CUNHA-SANTINO, MB., MILAN, JAM., RODRIGUES, CJ. and DIAS, JHP., 2010. Growth of Hydrilla verticillata (L.f.) Royle under controlled conditions. Hydrobiologia, vol. 644, no. 1, p. 301-312. http://dx.doi.org/10.1007/ s10750-010-0191-1.
BIANCHINI JUNIOR, I., CUNHA-SANTINO, MB., RIBEIRO, JU. and PENTEADO, DGB., 2014. Implication of anaerobic and aerobic decomposition of Eichhornia azurea (Sw.) Kunth. on the carbon cycling in a subtropical reservoir. Brazilian Journal of Biology $=$ Revista Brasileira de Biologia, vol. 74, no. 1, p. 100110. http://dx.doi.org/10.1590/1519-6984.17912. PMid:25055091

CHIBA DE CASTRO, WA., CUNHA-SANTINO, MB. and BIANCHINI JUNIOR, I., 2013. Anaerobic decomposition of a native and an exotic submersed macrophyte in two tropical reservoirs. Brazilian Journal of Biology $=$ Revista Brasileira de Biologia, vol. 73, no. 2, p. 299-307. http://dx.doi.org/10.1590/ S1519-69842013000200010. PMid:23917557

CUNHA-SANTINO, MB. and BIANCHINI JUNIOR, I., 2002. Humic substance mineralization in a tropical oxbow lake (São Paulo, Brazil). Hydrobiologia, vol. 468, no. 1-3, p. 33-43. http:// dx.doi.org/10.1023/A:1015214005279.

GILLON, D., JOFFRE, R. and IBRAHIMA, A., 1994. Initial litter properties and decay rate: a microcosm experiment on Mediterranean species. Canadian Journal of Botany, vol. 72, no. 7, p. 946-954. http://dx.doi.org/10.1139/b94-120.

HOORENS, B., AERTS, R. and STROETENGA, M., 2003. Does initial litter chemistry explain litter mixture effects on decomposition? Oecologia, vol. 137, no. 4, p. 578-586. http:// dx.doi.org/10.1007/s00442-003-1365-6. PMid:14505026

KOURTEV, PS., EHRENFELD JG. and HUANG, WZ., 2002. Enzyme activities during litter decomposition of two exotic and two native plant species in hardwood forests of New Jersey. Applied Soil Ecology, vol. 34, no. 9, p. 1207-1218.

PIETERSE, AH. and MURPHY, KJ. 1990. Aquatic Weeds. The ecology and management of nuisance aquatic vegetation. Oxford: Oxford Science Publications. 616 p.

REDDY, KR. and DELAUNE, RD. 2008. Biochemistry of wetlands - science and applications. Boca Raton: CRC Press. 774 p.

SOUSA, WTZ., THOMAZ, SM., MURPHY, KJ., SILVEIRA, MJ. and MORMUL, RP., 2009. Environmental predictors of the occurrence of exotic Hydrilla verticillata (L. f.) Royle and native Egeria najas Planch. in a sub-tropical river floodplain: the Upper River Paraná, Brazil. Hydrobiologia, vol. 632, no. 1, p. 65-78. http://dx.doi.org/10.1007/s10750-009-9828-3. 